\title{
HAK KONSTITUSIONAL WARGA NEGARA UNTUK BEKERJA PADA ERA REVOLUSI INDUSTRI 4.0
}

\section{THE CONSTITUTIONAL RIGHT OF CITIZENS TO WORK IN THE INDUSTRIAL REVOLUTION ERA 4.0}

\author{
Mardani Wijaya \\ Hukum Bisnis, Fakultas Hukum, Universitas Mataram \\ Jalan Majapahit No. 62 Kota Mataram, Nusa Tenggara Barat, 83127 \\ Email : mardaniwijaya3@gmail.com \\ Kurniawan \\ Dosen Universitas Mataram \\ email : kurniawan3377@gmail.com \\ Mohammad Sood \\ Dosen Universitas Mataram \\ email : muhammad_sood@unram.ac.id
}

\begin{abstract}
Abstrak
Tujuan penelitian ini adalah untuk menjawab pertanyaan apa tanggung jawab negara terhadap hak bekerja warga negara pada era revolusi industri 4.0 dan bagaimana sistem hukum ketenagakerjaan Indonesia menghadapi era revolusi industri 4.0. Penelitian ini adalah penelitian normatif dengan metode pendekatan perundangundangan dan pendekatan konseptual. Hak bekerja merupakan hak konstitusional yang dijamin dalam UUD 1945. Oleh karena itu, negara bertanggungjawab terhadap warga negaranya untuk mempertahankan hidup dan kehidupannya melalui bekerja pada era revolusi industri 4.0. Adapun tanggung jawab tersebut dijalankan melalui kebijakan-kebijakn yang dibuat untuk menghadapi era revolusi industri 4.0 yaitu dengan menerapkan kebijakan triple skilling yang dikeluarkan oleh Kementerian Ketenagakerjaan yang mencakup, pembentukan keterampilan dalam bentuk pelatihan vokasi bagi masyarakat yang belum memiliki keterampilan sehingga mereka dapat masuk ke pasar kerja atau berwirausaha, bertujuan untuk meningkatkan keterampilan agar tetap relevan dengan kebutuhan zaman dan kebijakan tersebut dapat diakses melalui pelatihan di BLK. Konsep negara kesejahteraan menempatkan peranan negara pada posisi yang kuat dan besar dalam menciptakan kesejahteraan umum (public welfare) dan keadilan sosial (social justice). Maka, sistem hukum ketenagakerjaan yang menciptakan kesejahteraan umum dengan tujuan untuk mempertahankan hak bekerja tenaga kerja manusia agar tidak tersingkirkan oleh adanya revolusi industri 4.0 merupakan langkah mewujudkan negara hukum kesejahteraan (welfare state).
\end{abstract}

Kata Kunci: Hak Konstitusional, Bekerja, Revolusi Industri 4.0

\begin{abstract}
The purpose of this study is to answer the question about state responsibility against the right of citizens to work in the industrial revolution era 4.0 and how Indonesia labor systems are facing the industrial revolution era 4.0. This research is normative legal research which using statute approach and conceptual approach. Right to work is the constitutional right that stated in The 1945 Constitution of the Republic of Indonesia
\end{abstract}


(UUD 1945). Therefore, the state has responsibility for the citizens to make them still survive in their live and have better live by still having job at the industry revolution 4.0. The responsibility of state has been doing recently by implemented policies to anticipate industrial revolution 4.0 through triple skilling program. The triple skilling program is a policy from Ministry of Manpower namely vocational training for people who do not have skills, for make them easier either getting job in the job markets or making a business. This training has a purpose to improve people skills that make them fulfill every job-specific skill on this era, on this policy anyone can be involved in the training at BLK. The welfare state concept establishes state in the strongest position to create public welfare and social justice. Furthermore, the employment law system creates public welfare foundation to make employees still have rights to work and they cannot exclude or remove by industry revolution 4.0, these are a way to realize welfare state concept.

\section{Keywords: Constitutional Right, Working, Industrial Revolution 4.0}

\section{PENDAHULUAN}

Pembangunan manusia dan masyarakat Indonesia seluruhnya untuk mewujudkan kesejahteraan (welfare), keadilan, kemakmuran yang merata, baik materiil maupun spiritual berdasarkan Pancasila dan Undang Undang Dasar Negara Republik Indonesia Tahun 1945 (UUD 1945) merupakan tujuan pembangunan nasional. Untuk mencapai tujuan tersebut, tenaga kerja mempunyai peranan dan kedudukan yang sangat penting. Maka, diperlukan peningkatan kualitas serta perlindungan terhadap tenaga kerja dan keluarganya sesuai dengan harkat dan martabat kemanusiaan sebagaimana amanat Pasal 27 ayat (2), Pasal 28A dan Pasal 28D ayat (2) UUD 1945, karena hak-hak asasi manusia tidak hanya terbatas pada hak-hak sipil dan politik (civil and political rights) melainkan juga hak-hak dibidang sosial dan ekonomi (social mensenrechten, subsistence rights), ${ }^{1}$ seperti hak atas pekerjaan.

Universal Declaration of Human Rights (UDHR) juga mengatur hak atas pekerjaan yang layak sebagaimana yang tertuang dalam Pasal 23 ayat (1) Everyone has the rights to work, to free choice of employment, a just a favourable conditions of work and to protection against unemployment dan ayat (2) Everyone without any discrimination, has the right equal pay for equal work. Dengan adanya jaminan negara terhadap hak asasi manusia untuk bekerja dan memeproleh imbalan/upah yang layak merupakan konsep negara kesejahteraan (welfare state) yang bertujuan untuk mensejahterakan rakyat banyak. ${ }^{2}$

Konsideran Undang-Undang Nomor 13 Tahun 2003 tentang Ketenagakerjaan (Undang-Undang Ketenagakerjaan) menerangkan bahwa perlindungan terhadap tenaga kerja dimaksudkan untuk menjamin hak-hak dasar pekerja/buruh dan menjamin kesamaan kesempatan serta perlakuan tanpa diskriminasi atas dasar apapun untuk mewujudkan kesejahteraan pekerja/buruh dan keluarganya dengan tetap memperhatikan perkembangan kemajuan dunia usaha. Definisi tenaga kerja dan pekerja dalam Pasal 1 angka 2 dan 3 Undang-Undang Ketenagakerjaan adalah "setiap orang yang mampu melakukan pekerjaan guna menghasilkan barang dan/atau jasa baik untuk memenuhi kebutuhan sendiri maupun untuk masyarakat"."pekerja/buruh setiap orang yang bekerja dengan menerima upah atau imbalan dalam bentuk lain".

Kata "setiap orang" dalam bunyi pasal tersebut di atas, apabila di interpretasikan secara gramatikal maka mengandung arti bahwa yang dapat menjadi tenaga kerja maupun pekerja/buruh adalah manusia. Salah satu bentuk perlindungn terhadap tenaga kerja atau pekerja/buruh agar terjamin kesempatannya dalam bekerja dapat terlihat

\footnotetext{
1 Bagir Manan, 2012, Membedah UUD 1945, Cetakan Pertama, UB Press, Malang, hlm. 23.

2 Jimly Asshidiqie, 1996, Pergumulan Peran Pemerintahan dan Parlemen Dalam Sejarah, Telaah Perbandingan Konstitusi Berbagai Negara, UI Press, Jakarta, hlm. 117.
} 
dalam ketentuan Pasal 151 ayat (1) Undang-Undang Ketenagakerjaan yang menyatakan bahwa "pengusaha, pekerja/buruh, serikat pekerja/serikat buruh, dan pemerintah, dengan segala upaya harus mengusahakan agar jangan terjadi pemutusan hubungan kerja", baik dengan cara pengaturan waktu kerja, penghematan, pembenahan metode kerja, dan memberikan pembinaan kepada pekerja/buruh.

Munculnya revolusi industri 4.0 menyebabkan sebagian pekerjaan yang biasanya dikerjakan oleh manusia akan hilang karena adanya era digitalisasi, otomatisasi dan robotisasi/kecerdasan buatan (Artificial Intelegency), dengan kata lain sebagian pekerjaan yang dulunya menggunakan tenaga kerja manusia akan digantikan oleh mesin seperti yang terjadi pada industri perbankan, para karyawan bank harap-harap cemas karena tengah menghadapi hal yang menakutkan dengan adanya revolusi industri 4.0. Dalam data yang dimiliki Jaringan Serikat Pekerja Perbankan Indonesia (Jarkom SP Perbankan), tercatat sejak 2016 sampai akhir 2018 sudah sebanyak 50.000 karyawan bank kena Pemutusan Hubungan Kerja (PHK), ${ }^{3}$ karena terdisrupsi (Disrupt) ${ }^{4}$ dengan adanya sistem digitalisasi tersebut. Dalam legal indutry juga Artificial Intelegency (AI) sering digunakan untuk review kontrak-kontrak bisnis, karena Artificial Intelegency tersebut memiliki tingkat akurasi $94 \%$ dan hanya membutuhkan waktu lebih singkat yaitu 26 detik dalam mereview kontrak-kontrak bisnis tersebut, sehingga dengan adanya Artificial Intelegency ini dapat mengambil sebagaian pekerjaan yang biasanya dikerjakan oleh advokat manusia. ${ }^{5}$

Revolusi industri terjadi untuk memenuhi hasrat keinginan dan kebutuhan manusia secara cepat dan berkualitas, sehingga perkembangan dunia bisnis membutuhkan inovasi sebagai langkah untuk mempertahankan eksistensi kegiatan bisnis suatu perusahaan. Inovasi adalah faktor paling penting yang menentukan daya saing suatu negara atau perusahaan. Hasil inovasi kedepan ditentukan sejauh mana dapat merumuskan body of knowladge terkait manajemen inovasi, technology transfer and business incubation, science and technopark. ${ }^{6}$

Kehadiran revolusi industri 4.0 yang sedang berlangsung saat ini memang disatu sisi, sebagian masyarakat berpendapat bahwa kemajuan teknologi kecerdasan buatan (Artificial Intelligence) di sektor industri merupakan sebuah keniscayaan yang tidak dapat dibendung dan menjadi ancaman terhadap tenaga kerja manusia yang akan tergantikan oleh robot atau sistem digitalisasi yang sedang berkembang, karena pabrikpabrik atau perusahaan nyaris tidak membutuhkan tenaga manusia, kecuali sedikit tenaga kerja manusia yang keahlian tertentu. Namun, disisi lain tenaga kerja manusia juga harus diberikan jaminan perlindungan dalam bentuk kepastian hukum terhadap hak-haknya untuk diberikan kesempatan kerja pada era revolusi industri 4.0 tersebut, karena merupakan hak asasi manusia yang diamanatkan dalam konstitusi yaitu UndangUndang Dasar Negara Republik Indonesia Tahun 1945 (UUD 1945). Maka, negara harus memberikan solusi atau alternatif bagi rakytanya untuk menghadapi perkembangan teknologi saat ini agar meberikan kepastian akan nasib para pekerja/buruh yang akan

\footnotetext{
${ }^{3}$ www.cnbcindonesia.com, Duh Tsunami PHK terjadi di Perbankan Indonesia, Diakses pada tanggal 31 Januari 2019 pukul 13.00 WITA.

${ }^{4}$ Disrupsi (Disrupt) adalah to prevent something, especially a system, process, or as usual or as expected; other meaning: to change the traditional way that an industry operates, especially in a new and effective way. TM. Luthfi Yazid, Disrupsi dan Hukum Masa Depan, Makalah disampaikan pada pertemuan ilmiah Taman Metajuridika Fakultas Hukum Universitas Mataram, tanggal 5 Januari 2019.

${ }^{5}$ Widodo Dwi Putro, Demetologisasi Metode Penelitian Hukum, Makalah disampaikan pada Seminar Metode Penelitian Hukum Fakultas Hukum Universitas Mataram pada tanggal 17 Januari 2019.

${ }^{6}$ Hendra Suwardana, Revolusi Industri 4.0 Berbasis Revolusi Mental, (Jurnal JATI UNIK), Vol. 1, No. 2, April 2018, hlm. 103-104.
} 
tersingkir dengan adanya sistem digitalisasi, otomatisasi dan robotisasi tersebut. Untuk itu, menarik dikaji terkait dengan hak konstitusi warga negara untuk bekerja pada era rovolusi industri 4.0 karena belum ada penelitian-penelitian yang mengkaji lebih mendalam tentang hak bekerja warga negara yang dijamin oleh konstitusi. Penelitian ini dapat memberikan masukan bagi pemerintah agar sistem hukum ketenagakerjaan yang dibuat kedepan dapat mengantisipasi kondisi pada era revolusi industri 4.0 tersebut sehingga dapat mewujudkan negara kesejahteraan (welfare state).

Berdasarkan uraian di atas, maka permasalahan yang dikaji dalam penelitian ini yaitu apa tanggung jawab negara terhadap hak bekerja warga negara pada era revolusi industri 4.0 dan bagaimana sistem hukum ketenagakerjaan Indonesia menghadapi era revolusi industri 4.0 .

Penelitianiniadalah penelitian normatifdengan menggunakan pendekatan perundangundangan (statute approach) dan pendekatan konseptual (statute conceptual). Jenis dan sumber bahan hukum dalam penelitian ini adalah bahan hukum primer yang terdiri dari Undang-Undang Dasar 1945 (UUD 1945) dan Undang-Undang Nomor 13 Tahun 2003 tentang Ketenagakerjaan (Undang-Undang Ketenagakerjaan), bahan hukum skunder yang terdiri dari literatur-literatur yang ada relevansinya dengan permasalahan yang dikaji. Teknik pengumpulan bahan hukum dilakukan dengan menelusuri bahan-bahan hukum dan buku-buku terkait dengak isu yang dikaji kemudian dianalisis menggunakan metode kualitatif dengan penalaran logika deduktif.

\section{PEMBAHASAN}

\section{Tanggung Jawab Negara Terhadap Hak Bekerja Warga Negara Pada Era Revolusi Industri 4.0}

Negara mengemban tiga tingkat tanggung jawab yaitu penghormatan, pemenuhan dan perlindungan hak asasi manusia yang tidak bisa dipisahkan satu dengan lainnya karena saling terikat. Penghormatan memerlukan peneguhan melalui pelaksanaan standar normatif yang mengakui hak asasi manusia tanpa kecuali merupakan syarat awal bagi penikmatan hak dan kebebasan. Negara perlu menciptakan lingkungan, termasuk kerangka kelembagaan yang memungkinkan pemenuhan stndar normatif tersebut. Negara juga harus mengembangkan mekanisme yang secara efektif melindungi standar-standar tersebut dari ancaman dan tindak pelanggaran. ${ }^{7}$

Ketentuan tentang hak asasi manusia yang termuat dalam UUD 1945 merupakan bentuk perlindungan atau penjaminan terhadap hak-hak warga negara (citizen's right) atau hak-hak konstitusional warga negara (the citizen's constitutional rights). ${ }^{8}$ Hak konstitusional memiliki lingkup domestik yang berlaku dalam hukum positif sebuah negara, ${ }^{9}$ yang secara substantif fungsi dan keberadaannya memuat hak-hak dasar seperti hak sipil dan politik, hak ekonomi, sosial dan budaya. ${ }^{10}$

Prinsip konstitusi yang paling utama menyangkut kerja adalah Pasal 27 ayat (2) yang menyatakan bahwa "tiap-tiap warga negara berhak atas pekerjaan dan penghidupan yang layak bagi kemanusiaan”. Rumusan Pasal 27 ayat (2) adalah rumusan yang ada sejak

\footnotetext{
${ }^{7}$ Tati Krisnawaty et al, 2010, Modul Pelatihan Pemenuhan Hak-Hak Konstitusi Warga Negara, Cetakan Ke. 2, Komnas Perempuan, Jakarta, hlm. 154.

8 www.uii.ac.id, Pentingnya Menjaga Hak Konstitusional Warga Negara di Indonesia, Diakses pada tanggal 9 Januari 2019 pukul 17.00 WITA.

${ }^{9}$ Bisariyadi, Menyibak Hak Konstitusional yang Tersembunyi, (Jurnal Hukum IUS QUIA IUSTUM), Vol. 24, No. 4, Oktober 2017, hlm. 514.

10 Ibid.
} 
mula diberlakukannya UUD 1945 sebagai hukum dasar di negara Indonesia. Menurut Ismail Suny sebagaimana dikutip dalam Agsumidah, ketentuan dalam Pasal 27 ayat (2) tersebut merupakan a paper constitution atau a semantic constitution. Dengan mengakui hak warga negaranya untuk mendapat pekerjaan maka sebenarnya Indonesia telah bertekad dan memutuskan untuk melenyapakn pengangguran dengan mewajibkan pemerintah untuk memberantas pengangguran dan harus mengusahakan supaya setiap warga negara bisa mendapat pekerjaan dengan nafkah yang layak untuk hidup. ${ }^{11}$ Lebih lanjut, hak atas pekerjaan tersebut, termuat juga dalam bab XA tentang hak asasi manusia.

Hak asasi manusia merupakan hak yang melekat (in alienable rights) pada diri manusia dari sejak dalam kandungan, sehingga negara wajib untuk memberikan pemenuhan, penghormatan dan perlindungan terhadap hak tersebut. Salah satu hak asasi manusia yaitu hak untuk mempertahankan hidup dan kehidupannya sebagaimana dalam UUD 1945 Pasal 28A yang menyatakan bahwa "setiap orang berhak untuk hidup serta berhak mempertahankan hidup dan kehidupannya". Pasal 28C ayat (1) menyatakan bahwa "setiap orang berhak mengembangkan diri melalui pemenuhan kebutuhan dasarnya, berhak mendapat pendidikan dan memperoleh manfaat dari ilmu pengetahuan dan teknologi, seni dan budaya, demi meningkatkan kualitas hidupnya dan demi kesejahteraan ummat".

Berdasarkan bunyi pasal tersebut, setiap orang dijamin oleh negara untuk mempertahankan hidupnya dengan cara apapun sepanjang tidak bertentangan dengan peraturan perundang-undangan yang berlaku, karena hak hidup merupakan hak fundamental (first order intraction) untuk menjaga keberlanjutan (sustainability) ${ }^{12}$ kehidupan setiap orang, maka harus dilindungi dan dihormtai. Negara mengemban tanggung jawab menjamin warga negara untuk mempertahankan hidup dan kehidupannya dalam memenuhi kebutuhan dasarnya demi meningkatkan kualitas hidup dan kesejahteraanya dengan salah satu caranya yaitu melalaui bekerja.

Setiap warga negara Indonesia mempunyai hak untuk mendapatkan kesempatan kerja dalam pelbagi lapangan kerja karena merupakan hak asasi manusia sebagaimana termuat dalam Pasal 28D UUD 1945 yang menyatakan bahwa "setiap orang berhak untuk bekerja serta mendapat mendapat imbalan dan perlakuan yang adil dan layak dalam hubungan kerja."

Hak untuk bekerja (right to work) memberikan pemahaman bahwa pemerintah/negara harus berupaya semaksimal mungkin membebaskan rakyatnya dari ketiadaan akan pekerjaan. Karena pekerjaan merupakan dasar bagi setiap orang mendapatkan jaminan kesejahteraan (welfare) bagi diri dan keluarganya dengan mendapatkan imbalan (upah) atas apa yang telah dikerjakannya. Dengan demikian, setiap kebijakan pemerintah harus dilihat dalam rangka mengurangi tingkat pengangguran serta meningkatkan kondisi kerja yang layak bagi kemanusiaan, karena merupakan kewajiban yang harus diwujudkan oleh negara. ${ }^{13}$

Suliati Rachmat mengatakan bahwa negara Republik Indonesia berkewajiban melindungi segenap bangsa Indonesia yang mencakup pula pekerja atau tenaga kerja dengan cara membentuk suatu peraturan perundang-undangan yang

\footnotetext{
${ }^{11}$ Agusmidah, 2011, Dilematika Hukum Ketenagakerjaan, Tinjauan Politik Hukum, Cet. I, Sofmedia, Jakarta, hlm. 208.

${ }^{12}$ Hayyanul Haq, Kekoherensian Pengembanan Hukum, Diskusi Taman Metajuridika Fakultas Hukum Universitas Mataram tanggal 20 April 2019.

${ }^{13}$ Agusmidah, Op. Cit., hlm. 214-215.
} 
melindungi hak pekerja, ${ }^{14}$ sebagai implementasi tanggungjawab negara terhadap hak asasi manusia untuk bekerja bagi warga negara Indonesia yang tertuang dalam konstitusi tersebut.

Negara harus mampu membuat suatu aturan tentang ketenagakerjaan yang dapat mengatasi disrupsi tenaga kerja pada era revolusi industri 4.0 untuk memenuhi amanat konstitusi yang memberikan tanggung jawab kepada negara untuk melindungi hak asasi manusia dalam mempertahankan hidup dan kehidupannya melalui bekerja dan mencapai tujuan hukum yang dapat mewujudkan kebahagiaan yang sebesar-besarnya untuk sebanyak-banyak orang. Senagaimana yang diungkapkan oleh Jeremy Bentham yang dikenal dengan aliran utilitarianismenya bahwa peraturan perundang-undangan harus berusaha mencapai 4 (empat) tujuan yaitu, to provide substance, to provide abundance, to provide scurity dan to attain equality. ${ }^{15}$

Peraturan perundang-undangan yang mengatur tentang hukum ketenagakerjaan harus mampu memberikan kesejahteraan untuk pekerja/buruh atau tenaga kerja, memberikan perlindungan dan mensejajarkan posisi tenaga kerja atau pekerja/ buruh dan pengusaha. Bentuk perlindungan tersebut dapat berupa usaha untuk agar sebisa mungkin tidak terjadi Pemutusan Hubungan Kerja (PHK) sebagaimana dalam Undang-Udnang Nomor 13 Tahun 2003 tentang Ketenagakerjaan (Undang-Undang Ketenagakerjaan) Pasal 151 ayat (1) yang menyatakan bahwa "Pengusaha, pekerja/buruh, serikat pekerja/serikat buruh, dan pemerintah, dengan segala upaya harus mengusahakan agar jangan terjadi pemutusan hubungan kerja". Pemerintah harus berperan aktif dalam memberikan sebuah keadilan bagi seluruh tenaga kerja atau buruh/pekerja yang bermanfaat baik dalam bentuk norma dan implementasinya agar tercapai kesejahteraan bagi pekerj/buruh atau tenaga kerja pada era revolusi industri 4.0.

Pemerintah melalui melalui Kementerian Perindustrian telah menyusun inisiatif "Making Indonesia 4.0" untuk mengimplementasikan strategi dan Peta Jalan 4IR di Indonesia. Peta Jalan ini melibatkan berbagai pemangku kepentingan, mulai dari institusi pemerintah, asosiasi industri, pelaku usaha, penyedia teknologi, maupun lembaga riset dan pendidikan. Peta Jalan Making Indonesia 4.0 memberikan arah dan strategi yang jelas bagi pergerakan industri Indonesia di masa yang akan datang, termasuk di lima sektor yang menjadi fokus dan 10 prioritas nasional dalam upaya memperkuat struktur perindustrian Indonesia. Melalui komitmen serta partisipasi aktif dari berbagai pemangku kepentingan, termasuk di dalamnya kementerian dan lembaga pemerintah lainnya, kemitraan dengan pihak swasta dan pelaku industri terkemuka, investor, institusi pendidikan lembaga riset, kami yakin cetak biru Making Indonesia 4.0 dapat dijalankan dengan sukses. ${ }^{16}$

Menteri Ketenagakerjaan telah menyiapkan tiga strategi transformasi bagi industri dalam menghadapi revolusi industri 4.0 yakni industry transformation strategy, future jobs, dan manpower planning. Dengan adanya perubahan jenis pekerjaan, keterampilan yang dibutuhkan ikut berubah, sehingga butuh pemetaan apa saja keterampilan yang dibutuhkan dan tidak. Strategi tersebut yaitu meningkatkan link and match antara supply and demand Sumber Daya Manusia (SDM), masifikasi pelatihan

\footnotetext{
${ }^{14}$ Suliati Rachmat, Upaya Peningkatan Perlindungan Hukum Wanita Pekerja di PerusahaanIndustri Swasta, Disertasi, Program Pascasarjana Universitas Indonesia, Jakarta, 1996, hlm. 10.

${ }^{15}$ Mahdi Bin Achmad Mahfud dan Vinaricha Sucika, Hukum Ketenagakerjaan dan Perkembangannya, R.A.De. Rozaeri, Anggota IKAPI, Surabaya, 2014, hlm. 17.

16 www.kemenperin.go.id, Making Indonesia 4.0: Bikin Industri Nasional Berdaya Saing Global di Era Digital, Diakses pada tanggal 10 April 2019 pukul 15.00 WITA.
} 
kerja dan sertifikasi profesi serta pemagangan berbasis jabatan. ${ }^{17}$ Dengan adanya peningkatan keterampilan melalui pelatihan-pelatihan kerja seperti peningkatan pengusaan tenaga kerja atau buruh/pekerja terhadap informasi teknologi (IT) untuk mengeksplor bakat-bakat yang dimiliki oleh tenaga kerja atau buruh/pekerja yang dibutuhkan oleh dunia usaha saat ini merupakan salah satu solusi yang diterapkan untuk menghadapi era revolusi industri 4.0 yang diharapkan dapat meningkatkan kompetensi tenaga kerja atau buruh/pekerja agar tidak terdisrupsi oleh sistem digitalisasi dan otomatisasi tersebut.

Berdasarkan rencana pemerintah melalui beberapa kementerian untuk mengatasi revolusi industri 4.0 tersebut merupakan langkah negara untuk memenuhi tanggung jawabnya melindungi hak-hak kosntitusional warga negara untuk bekerja dan memperoleh imbalan yang layak atas hasil kerjanya sebagaimana amanat konstitusi negara Indonesia.

\section{Sistem Hukum Ketenagakerjaan Indonesia Menghadapi Era Revolusi Industri 4.0}

Teori negara hukum kesejahteraan merupakan perpaduan antara negara hukum dan negara kesejahteraan. Menurut Burknes sebagaimana yang dikutip oleh Mochtar Kusumaatmadja, negara hukum (rechtstaat) adalah negara yang menempatkan hukum sebagai dasar kekuasaanya dan penyelenggaraan kekuasaan tersebut dalam segala bentuknya dilakukan di bawah kekuasaan hukum. ${ }^{18}$ Seadangkan konsep negara kesejahteraan menurut Neville Harris sebagaimana dikutip dalam Aktieva Tri Tjitrwati adalah "The form of democratic government that places the state as the institution that is responsible towards welfare of the people, through a series of public policy in integrating the economic policy and the social policy for the achievement of welfare and social justice". ${ }^{19}$

Negara hukum kesejahteraan merupakan negara yang menempatkan hukum sebagai dasar dalam penyelenggaraan kekauasaan yang bertanggung jawab terhadap kesejahteraan rakyat melalui kebijakan-kebijakan yang dibuat oleh pemerintah dengan tujuan untuk menciptakan kesejahteraan dan keadilan sosial. Peran negara dalam mewujdukan kesejahteraan rakyat merupakan amanat konstitusi yang harus dijalankan oleh pemerintah untuk menjamin agar terpenuhi hak-hak konstitusional warga negaranya, terlebih dalam memenuhi dan melindungi hak-hak kesempatan bekerja warga negara pada era revolusi industri 4.0.

Penataan sistem penyelenggaraan ekonomi yang berpihak kepada rakyat tidak terlepas dari fungsi negara itu sendiri dalam bidang ekonomi. Friedman dalam bukunya The rule of law and the welfare state menyebutkan adanya lima fungsi negara kesejahteraan yaitu sebagai protector, provider, regulator, enterpreneur dan arbitrator. Negara dalam menjalankan fungsi-fungsinya harus memiliki lembaga-lembaga dan standar perlakuan yang menjamin terselenggaranya kesejahetraan sosial yang diatur melalui perangkat hukum. ${ }^{20}$ Fungsi negara sebagai protector (perlindungan) merupakan fungsi yang sangat penting dalam sistem pemerintahan di suatu negara, baik dalam bentuk perlindungan yang sifatnya pencegahan (preventif) maupun perlindungan yang sifatnya penindakan (represif). Melalui fungsi perlindungan tersebut, negara mempunyai kewajiban

${ }^{17}$ www.hukumonline.com, Regulasi Ketenagakerjaan Mesti Adopsi Perkembangan Revolusi Industri 4.0, Diakses pada tanggal 11 April 2019 pukul 09.15 WITA.

${ }^{18}$ Mochtar Kusumaatmadja, 1995, "Pemantapan Cita Hukum dan Asas-Asas Hukum Nasional di Masa Kini dan Masa yang Akan Datang”, Edisi Khusus, No. 1, Majalah Hukum Nasional, Jakarta, hlm. 1.

${ }^{19}$ Aktieva Tri Tjitrawati, The Just Drug Distribution In The Perspective Of Welfare State, (Jurnal Mimbar Hukum), Vol. 25. No. 3, Oktober 2013, hlm. 530.

${ }^{20}$ Rusnan, Konsep Negara Hukum Dalam Hubungan Kekuasaan Freiss Ermerssen Dalam Welfare State, (Jurnal Ilmu Hukum Ius Kajian Hukum dan Keadilan), Vol. II, No. 4, April 2014, hlm. 6. 
untuk memberikan jaminan perlindungan hak-hak konstitusional rakyatnya. Fungsi provider (pemberi), tanggung jawab negara untuk memberikan jaminan pelayanan atas terselenggaranya kesejahteraan sosial.

Regulator (pengatur), negara memiliki kewenangan untuk membuat peraturanperaturan yang menciptakan kesejahteraan bagi rakyatnya, seperti Undang-Undang Ketenagakerjaan yang harus mampu untuk mewujudkan kesejahteraan bagi tenaga kerja atau pekerja/buruh melalui kesempatan bekerja yang sama antar sesama warga negara. Fungsi negara sebagai enterpreneur, negara bukan hanya berfungsi untuk menciptakan keamanan dan ketertiban akan tetapi negara juga harus mampu mengusahakan sumber daya yang dikuasainya untuk memperoleh keuntungan/pendapatan sebagai langkah meningkatkan perekonomian negara yang semata-mata untuk tujuan kemakmuran dan kesejahteraan rakyat. Fungsi negara sebagai arbitrator dalam arti bahwa negara sebagai penengah dalam hal terjadinya konflik-konflik sosial yang ada dalam masyarakat. Konsepsi negara kesejahteraan (welfare state) atau negara hukum modern/negara hukum materiil memiliki ciri-ciri sebagai berikut: ${ }^{21}$

1. Negara hukum kesejahteraan lebih mengutamakan terjaminnya hak-hak asasi sosial ekonomi rakyat, seperti hak warga negara untuk bekerja serta memperoleh imbalan yang layak.

2. Peranan ekskutif lebih besar daripada legislatif, karena pertimbangan-pertimbangan efisiensi dan manajemen lebih diutamakan dibanding pembagian kekuasaan yang berorientasi politis.

3. Hak milik tidak bersifat mutlak.

4. Negara tidak hanya menjaga ketertiban dan keamanan atau penjaga malam (Nachwakerstaat), melainkan negara turut serta dalam usaha-usaha sosial maupun ekonomi.

5. Kaidah-kaidah hukum administrasi semakin banyak mengatur sosial ekonomi dan membebankan kewajiban tertentu kepada warganegara.

6. Peranan hukum publik condong mendesak hukum privat, sebagaikonsekuensi semakin luasnya peranan negara

7. Lebih bersifat negara hukum materiil yang mengutamakan keadilan keadilan sosial yang materiil pula.

Berdasarkan ciri-ciri di atas, jelaslah bahwa dalam konsep negara hukum kesejahteraan peranan negara pada posisi yang kuat dan besar dalam menciptakan kesejahteraan umum (public welfare) dan keadilan sosial (social justice). Maka, dalam menghadapi era revolusi industri 4.0 ini, negara harus merespon perkembangan dunia bisnis yang terjadi khususnya dibidang ketenagakerjaan, dengan menciptakan suatu aturan-aturan yang dapat mengakomodir dunia bisnis yang serba digitalisasi atau otomatisasi sehingga tenaga kerja manusia tidak tersingkirkan oleh adanya sistem yang serba online tersebut, karena negara berkewajiban untuk menjamin warga negaranya memperoleh hak untuk bekerja sebagai langkah untuk mempertahankan hidup dan kehidupannya sebagaimana amanat dari konstitusi negara Indonesia yaitu UUD 1945. Sehingga apa yang dikatakan oleh Philippe Nonet dan Philip Selznick, bahwa hukum harus merespon perkembangan kehidupan manusia yang selalu berubah-ubah atau yang sering disebut dengan hukum responsip dapat diimplementasikan melalui suatu regulasi ketenagakerjaan di Indonesia.

Fungsi konstitusi adalah sebagai guardian of fundamental rights yang memiliki arti penting dalam rangka menciptakan keseimbangan antara penyelenggaraan kekuasaan

\footnotetext{
${ }^{21}$ Lalu Husni, Hukum Penempatan dan Perlindungan TKI, Cetakan Kedua, Program Pasca Sarjana, Universitas Brawijaya, Malang, 2015, hlm. 32.
} 
dalam negara dan melindungi hak-hak dasar warga negara, sesungguhnya seluruh warga negara merupakan rakyat yang memegang kedaulatan tertinggi. Rakyat sebagai pemegang kedaulatan memiliki jaminan perlindungan atas hak-hak dasarnya. ${ }^{22}$ Oleh karena itu, hak konstitusional warga negara untuk bekerja tidak boleh dikesampingkan dengan adanya perkembangan dunia bisnis yang serba digital dan otomatis (era revolusi industri 4.0). Karena, negara bertanggungjawab untuk melindungi hak-hak konstitusional warga negaranya, seperti hak ekonomi. Sebagai langkah untuk merespon perkembangan dunia usaha sekarang ini, pemerintah perlu merevisi Undang-Undang Nomor 13 Tahun 2003 tentang Ketenagakerjaan (Undang-Undang Ketenagakerjaan), karena sudah tidak bisa mengakomodir perkembangan dunia usaha pada era revolusi industri 4.0 tersebut seperti pengaturan hubungan kerja yang diatur dalam sistem hukum ketenagakerjaan tersebut.

Hubungan kerja dalam Undang-Undang Ketenagakerjaan adalah hubungan antara pengusaha dengan pekerja/buruh berdasarkan kesepakatan kedua belah pihak, kemampuan atau kecakapan melakukan perbuatan hukum, adanya pekerjaan yang diperjanjikan. Hubungan kerja yang muncul pada era revolusi industri 4.0 tidak seperti hubungan kerja sebagaimana yang diatur dalam Undang-Undang Ketenagakerjaan tersebut. Hubungan antara pemberi kerja dengan penerima kerja (tenaga kerja atau buruh/pekerja) bukan lagi hubungan permanen dan statis tetapi bersifat parnership, sehingga tenaga kerja atau buruh/pekerja bisa saja bekerja untuk bebrapa perusahaan yang berbeda. Dalam hubungan kerja tersebut waktu yang digunakan untuk bekerja lebih fleksibel dan tempat kerjanya tidak harus selalu dalam suatu gedung. Dalam hal gaji tenaga kerja atau buruh/pekerja, dengan menggunakan hubungan kerja yang sifatnya partnership tersebut penghitungan pembayaran gaji bisa saja tidak menggunakan sistem bulanan seperti biasanya namun dibayarkan dalam hitungan jam, hari, minggu atau bulanan tergantung kesepakatan dan tingkat keahliannya. Sehingga, dengan hubungan kerja dan sistem pembayaran gaji seperti itu, kalau terjadi Pemutusan Hubungan Kerja (PHK) maka tenaga kerja atau buruh/pekerja tidak akan mendapatkan pesangon karena hubungan kerja yang sifatnya pertemanan (partenrship). Dengan adanya perkembangan-perkembangan yang ada tersebut, maka tidak ada alasan lagi bagi pemerintah untuk tidak merevisi sistem hukum ketenagakerjaan agar dapat mengakomodir semua perkembangan bisnis terlebih dalam dunia ketenagakerjaan untuk menciptakan kesejahteraan bagi tenaga kerja atau buruh/ pekerja pada era revolusi industri 4.0

Konsep negara hukum kesejahteraan dalam konteks Indonesia, dapat dilihat dalam Pembukaan UUD 1945 alinea ke empat yang merupakan tujuan negara Republik Indonesia yaitu untuk melindungi segenap bangsa Indonesia dan seluruh tumpah darah Indonesia dan untuk memamjukan kesejahteraan umum. Lebih khusus lagi kalau kita melihat Pasal 4 Undang-Undang Ketenagakerjaan sebagai aturan yang berada di bawah UUD 1945 terkait dengan tujuan pembangunan ketenagakerjaan yaitu:

a) Memberdayakan dan mendayagunakan tenaga kerja secara optimal dan manusiawi;

b) Mewujudkan pemerataan kesempatan kerja dan penyediaan tenaga kerja yang sesuai dengan kebutuhan pembangunan nasional dan daerah;

c) Memberikan perlindungan kepada tenaga kerja dalam mewujudkan kesejahteraan; dan

d) Meningkatkan kesejahteraan tenaga kerja dan keluarganya.

\footnotetext{
${ }^{22}$ Bisariadi, Op. Cit., hlm. 513.
} 
Hukum ketenagakerjaan tidak lepas dari teori negara hukum kesejahteraan, karena hukum ketenagakerjaan merupakan suatu regulasi yang bertujuan untuk menciptakan kesejahteraan bagi pekerja/buruh atau tenaga kerja. Sebagaimana dalam konsideran undang-undang ketenagakerjaan yang mengatakan bahwa pembangunan masyarakat Indonesia seluruhnya untuk mewujudkan masyarakat yang sejahtera, adil, makmur, yang merata, baik materiil maupun spiritual berdasarkan Pancasila dan Undang Undang Dasar Negara Republik Indonesia Tahun 1945.

Rencana pelatihan tenaga kerja atau buruh/pekerja yang sifatnya untuk kebutuhan jangka pendek dan jangka panjang harus diperhatikan oleh pemerintah, seperti membuat pelatihan-pelatihan kerja yang dapat meningkatkan kemampuan dan produktivitas tenaga kerja atau buruh/pekerja sesuai dengan kebutuhan dunia usaha saat ini seperti meningkatkan skil di bidang informasi teknologi (IT), karena pengusaan terhadap teknologi saat ini sangat dibutuhkan untuk menunjang kegiatan-kegiatan bisnis pada era revolusi industri 4.0. Tenaga kerja mempunyai peranan dan kedudukan yang sangat penting sebagai pelaku dan tujuan pembangunan. Untuk itu, pemerintah berkewjiban untuk memberikan perlindungan terhadap tenaga kerja dimaksudkan untuk menjamin hak-hak dasar pekerja/buruh dan menjamin kesamaan kesempatan serta perlakuan tanpa diskriminasi atas dasar apapun untuk mewujudkan kesejahteraan pekerja/buruh dan keluarganya dengan tetap memperhatikan perkembangan kemajuan dunia usaha, karena zaman yang terus semakin berkembang seperti saat ini dimana dunia usaha atau kegiatan bisnis yang konvensional terdisrupsi dengan munculnya dunia usaha yang serba digitalisasi dan otomatisasi atau yang sering disebut sebagai era revolusi industri 4.0.

Perlindungan atas hak-hak tenaga kerja atau buruh/pekerja harus menjadi prioritas utama bagi pemerintah dalam menghadapi era revolusi industri 4.0. Dibutuhkan sistem hukum ketenagakerjaan yang mamapu memberikan jaminan kepastian atas hak-hak tenaga kerja atau buruh/pekerja agar mampu bersaing dengan perkembangan dunia bisnis saat ini yang serba digital dan otomatis. Terpenuhinya hak-hak konstitusional warga negara untuk bekerja pada era revolusi industri 4.0 tersebut dapat mewujudkan kesejahteran rakyat sebagaimana tujuan dalam negara hukum kesejahteraan (welfare state).

\section{SIMPULAN}

Hak bekerja warga negara dijamin dalam UUD 1945. Oleh karena itu, negara bertanggungjawab terhadap warga negaranya untuk mempertahankan hidup dan kehidupannya melalui bekerja pada era revolusi industri 4.0. Adapun tanggung jawab tersebut dijalankan melalui kebijakan-kebijakan yang dibuat untuk menghadapi era revolusi industri 4.0 yaitu dengan menerapkan kebijakan triple skilling yang dikeluarkan oleh Kementerian Ketenagakerjaan yang mencakup, pembentukan keterampilan dalam bentuk pelatihan vokasi bagi masyarakat yang belum memiliki keterampilan sehingga mereka dapat masuk ke pasar kerja atau berwirausaha, bertujuan untuk meningkatkan keterampilan agar tetap relevan dengan kebutuhan zaman dan kebijakan tersebut dapat diakses melalui pelatihan-pelatihan kerja di BLK.

Konsep negara kesejahteraan menempatkan peranan negara pada posisi yang kuat dan besar dalam menciptakan kesejahteraan umum (public welfare) dan keadilan sosial (social justice). Maka, sistem hukum ketenagakerjaan yang menciptakan kesejahteraan umum dengan tujuan untuk mempertahankan hak bekerja tenaga kerja manusia agar 
tidak tersingkirkan oleh adanya revolusi industri 4.0 merupakan langkah mewujudkan negara hukum kesejahteraan (welfare state).

\section{DAFTAR PUSTAKA}

\section{Buku}

Agusmidah, 2011, Dilematika Hukum Ketenagakerjaan, Tinjauan Politik Hukum, Cet. I, Sofmedia, Jakarta.

Bagir Manan, 2012, Membedah UUD 1945, Cetakan Pertama, UB Press, Malang.

Jimly Asshidiqie, 1996, Pergumulan Peran Pemerintahan dan Parlemen Dalam Sejarah, Telaah Perbandingan Konstitusi Berbagai Negara, UI Press, Jakarta.

Lalu Husni, 2015, Hukum Penempatan dan Perlindungan TKI, Cetakan Kedua, Program Pasca Sarjana, Universitas Brawijaya, Malang.

Mahdi Bin Achmad Mahfud dan Vinaricha Sucika, 2014, Hukum Ketenagakerjaan dan Perkembangannya, R.A.De.Rozaeri, Anggota IKAPI, Surabaya.

Tati Krisnawaty et al, 2010, Modul Pelatihan Pemenuhan Hak-Hak Konstitusi Warga Negara, Cetakan Ke. 2, Komnas Perempuan, Jakarta.

\section{Jurnal dan karya ilmiah lain}

Aktieva Tri Tjitrawati, The Just Drug Distribution In The Perspective Of Welfare State, Jurnal Mimbar Hukum, Vol. 25. No. 3, Oktober 2013.

Bisariyadi, Menyibak Hak Konstitusional yang Tersembunyi, Jurnal Hukum IUS QUIA IUSTUM, No. 4, Vol. 24, Oktober 2017.

Hayyanul Haq, 2019, Kekoherensian Pengembanan Hukum, Diskusi Taman Metajuridika Fakultas Hukum Universitas Mataram, 20 April.

Hendra Suwardana, Revolusi Industri 4.0 Berbasis Revolusi Mental, Jurnal JATI UNIK, Vol. 1, No. 2, April 2018.

Mochtar Kusumaatmadja, Pemantapan Cita Hukum dan Asas-Asas Hukum Nasional di Masa Kini dan Masa yang Akan Datang. Majalah Hukum Nasional, No. 1, Edisi Khusus 1995, hlm. 1.

Rusnan, Konsep Negara Hukum Dalam Hubungan Kekuasaan Freiss Ermerssen Dalam Welfare State, Jurnal Ilmu Hukum Ius Kajian Hukum dan Keadilan, Vol. II, No. 4, April 2014.

Suliati Rachmat, 1996, Upaya Peningkatan Perlindungan Hukum Wanita Pekerja di Perusahaan Industri Swasta, Disertasi, Fakultas Hukum, Program Pascasarjana, Universitas Indonesia, Jakarta.

TM. Luthfi Yazid, 2019, Disrupsi dan Hukum Masa Depan, Pertemuan Ilmiah Taman Metajuridika Fakultas Hukum Universitas Mataram, 5 Januari.

Widodo Dwi Putro, 2019, Demetologisasi Metode Penelitian Hukum, Seminar Metode Penelitian Hukum Fakultas Hukum Universitas Mataram, 17 Januari.

\section{Peraturan Perundang-Undangan}

Undang-Undang Dasar Negara Republik Indonesia Tahun 1945

\section{IUS Kajian Hukum dan Keadilan}


Undang-Undang 13 Tahun 2003 tentang Ketenagakerjaan (Lembaran Negara Republik Indonesia Tahun 2003 Nomor 39, Tambahan Lembaran Negara Republik Indonesia Nomor 4279)

\section{Website}

www.uii.ac.id, "Constitutional Court and The Protection of Citizen's Constitutional Rights", Diakses pada tanggal 9 Januari 2019.

www.cnbcindonesia.com, "Duh, Tsunami PHK Terjadi di Perbankan Indonesia?", Diakses pada tanggal 31 Januari 2019.

www.kemenperin.go.id, "Making Indonesia 4.0 Bikin Industri Nasional Berdaya Saing Global di Era Digital", Diakses pada tanggal 10 April 2019.

www.hukumonline.com, "Regulasi Ketenagakerjaan Mesti AdopsiPerkembangan Revolusi Industri 4.0: Antara lain berpotensi mengubah bentuk hubungan kerja, pola kerja, pilihan lembaga penyelesaian sengketa", Diakses pada tanggal 11 April 2019. 